\title{
AN EARLY VALIDATION OF IMAGE PROCESSING TECHNIQUE FOR FLATNESS MEASUREMENT An Early Validation of Image Processing Technique for Flatness Measurement
}

\author{
Rima Zuriah Amdani1, Eka Pratiwi2, Nadya Larasati Kartika 3 and Muhammad Azzumar4 \\ ${ }^{1}$ Balai Penelitian Teknologi Bahan Alam-LIPI, Yogyakarta \\ Jalan Jogja-Wonosari KM 31,5 55861, Gunung Kidul, Yogyakarta \\ 2, 4 Pusrisbang-BSN \\ Kompleks Puspiptek Gedung 42015314 Serpong, Tangerang Selatan \\ ${ }^{3}$ Pusat Penelitian Elektronika dan Telekomunikasi-LIPI \\ Jalan Sangkuriang Komplek Perkantoran LIPI Gedung 20 40135, Cisitu, Bandung \\ email: rima004@lipi.go.id
}

Diterima: 16 April 2019, Direvisi: 2 Agustus 2019, Disetujui: 12 November 2019

\begin{abstract}
An experimental validation of flatness measurement based on image processing technique has been performed. The purpose of this study is to know the performance of the image processing technique in the flatness measurement. In addition, this technique will be used as development of current measurement technique that is performed manually. The advantage of using this method is that in the future the measurement system will run semi-automatically, so it can increase the capacity. This study is used 3 samples of optical flat with different in diameter (i.e. $25 \mathrm{~mm}, 45 \mathrm{~mm}$, and $75 \mathrm{~mm}$ ). The validation has been performed by comparing measurement results of the image processing technique and the manual technique through degree of equivalence evaluation. The error numbers based on the degree of equivalence criteria between the image processing technique and the manual technique for the flatness measurement of $25 \mathrm{~mm}, 45 \mathrm{~mm}$, and $75 \mathrm{~mm}$ are $0.02,0.09$, and 0.11 respectively. According to those error numbers, the image processing technique measurement results is in agreement with the manual technique. Moreover, those results have validated that the image processing technique has good performance and can potentially be implemented to the flatness measurement.
\end{abstract}

Keywords : Flatness measurement, image processing technique, validation

\begin{abstract}
Abstrak
Validasi eksperimental pengukuran kerataan berdasarkan teknik pemrosesan gambar telah dilakukan. Tujuan dari penelitian ini adalah untuk mengetahui kinerja teknik pengolahan citra dalam pengukuran kerataan. Selain itu, teknik ini akan digunakan sebagai pengembangan teknik pengukuran saat ini yang dilakukan secara manual. Manfaat dari penggunaan methode ini adalah kedepannya pengukuran akan berjalan semi otomatis sehingga meningkatkan kapasitas penerimaan order. Penelitian ini menggunakan 3 sampel flat optik dengan diameter berbeda (mis. $25 \mathrm{~mm}, 45 \mathrm{~mm}$, dan $75 \mathrm{~mm}$ ). Verifikasi telah dilakukan dengan membandingkan hasil pengukuran dari teknik pemrosesan gambar dan teknik manual melalui tingkat evaluasi kesetaraan. Angka kesalahan berdasarkan tingkat kriteria kesetaraan antara teknik pemrosesan gambar dan teknik manual untuk pengukuran kerataan $25 \mathrm{~mm}, 45 \mathrm{~mm}$, dan $75 \mathrm{~mm}$ masing-masing adalah 0,02, 0,09, dan 0,11. Menurut angka-angka kesalahan itu, hasil pengukuran teknik pemrosesan gambar memiliki perjanjian nilai pengukuran dengan hasil pengukuran teknik manual. Selain itu, hasil tersebut telah memvalidasi bahwa teknik pemrosesan gambar memiliki kinerja yang baik dan dapat diimplementasikan ke pengukuran kerataan. Kata Kunci : pengukuran kerataan, teknik pemrosesan gambar, verifikasi

A simplest method for measuring flatness is direct comparison with an optical reference. The comparison can be performed using

combination of several optical flats to minimize the uncertainty measurement ( $\mathrm{Xu}$, Chen \& Yin, 2009). Optical interferometry has been known as a precise method to measure optical flat (De Groot, Biegen, Clark, de Lega \& Grigg, 2002). However, flatness
\end{abstract}

\section{INTRODUCTION}


measurement system established in Standardisation Agency of Indonesia (SNSUBSN) is based on interference phenomena in a thin film. The interference produces dark light pattern called fringe. The curvature of the fringes pattern indicates the optical flatness. The reading of fringe pattern form is observed manually by naked eyes. It causes human error factor on subjectivity for determining the edge of fringe.

Flatness measurement system by image processing technique is presented to development the current measurement technique that is performed manually. Edge detection capability is fundamental in image processing technique since the edge detection is the initial step in object recognition. There are several edge detection methods available such as Prewitt, Sobel, and Kircsh (Rashmi, Kumar \& Saxena, 2013). It is necessary to select a fit edge detection method. Those edge detection methods have some disadvantages such as sensitive to noise and malfunction at the curves. Canny method has advantage for giving better detection especially in noise conditions and using probability for finding error rate. The program is developed using MATLAB (Gonzalez, Woods \& Eddins, 2009). Image area and which desired fringe in the image is still selected manually. Before applying the edge detection by Canny method, the threshold value is carry out by using Otsu calculation. Then, in this experiment, the computation of flatness measurement value in the fringe image is based on ratio between fringe deviation width and fringe spacing width that has been performed using the Canny methods. The measurement is taken in 10 points along the selected fringe.

The purpose of this study is to know the performance of the image processing technique in the flatness measurement. An early validation to prove image processing technique is needed to ensure that this method is applicable for measuring flatness of the optical flat. The validation is performed by comparing measurement results of the image processing technique and the manual technique through degree of equivalence evaluation. If the image processing technique measurement results have the measuring value agreement with the manual technique measurement results, it means those results have verified that the image processing technique has good performance and can be implemented to the flatness measurement. This study used 3 samples of optical flats with different in diameter (i.e. $25 \mathrm{~mm}, 45 \mathrm{~mm}$, and $75 \mathrm{~mm}$ ).

\section{BASIC THEORY}

When an optical flat test is placed on optical flat standard, thin air gap will be formed between the two surface due to imperfection form of the two surfaces. If it is illuminated by a monochromatic light source, a series of dark light pattern called fringe will be formed. This fringe pattern is based on the interference phenomena in thin film. The interference occurs due to phase difference between two or more waves with the same wavelength. Phase difference caused by different path length and phase reversal. The illustration of the interference phenomena in thin film is presented in Figure 1 (Air Wedge Interference Picture, n.d.).

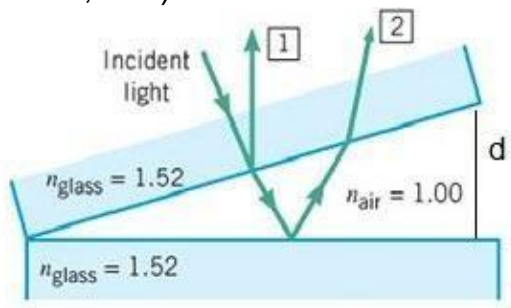

Figure 1 Interference phenomena illustration.

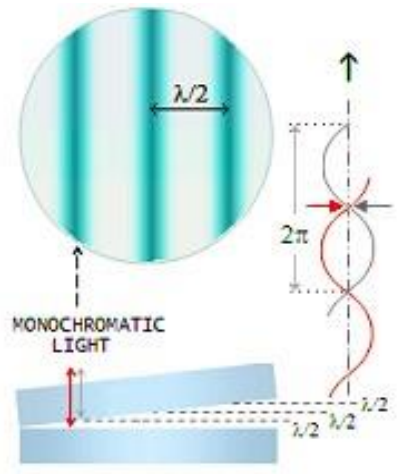

Figure 2 Fringe pattern.

$\mathrm{d}$ is the air gap or thin film between two surfaces. The incident light will be directly reflected as the light beam 1 , and refracted first as light beam 2 . There will be path length difference between light beam 1 and 2. Both light beam passing through different medium that caused phase reversal. Illustration of fringe pattern generated from the interference phenomena is shown in Figure 2 (Interference Pattern Formation Picture,n.d.).

The number of fringes present indicates the width of the air gap and not indicates flatness of the test piece. The fringe pattern curvature indicates the optical flatness. Evaluation of the optical flatness can be 
obtained by using equation (1) (JIS B 7430$7431,1977)$ and the illustration of fringe deviation width (b) and fringe spacing width (a) is shown in Figure 3

$$
\mathrm{F}=\frac{b}{a} x_{2}^{2}
$$

where:

$$
\begin{aligned}
& F=\text { flatness value } \\
& b=\text { fringe deviation width } \\
& a=\text { fringe spacing width } \\
& \lambda=\text { wavelength of monochromatic lamp }
\end{aligned}
$$

Digital single-lens reflex camera or DSLR camera is widely used for photography purposes. It is equipped with CMOS sensor that has excellent feature to be alternative instrument for scientific purpose (Firmansyah, Priyatikanto \& Aria, 2015). Recognition of an image can be obtained by applied edge detection methods. General edge detection methods that widely used are Roberts, Prewitt, Sobel, and Canny method. Among the mentioned method, Canny method give the better edge detection results of an image because using probability for finding error rate. It will improve the signal to noise ration (SNR), then in the noisy condition, the better detection is achieved. This result is proved by (AboZahhad, Gharieb, Ahmed \& Donkol, 2014).

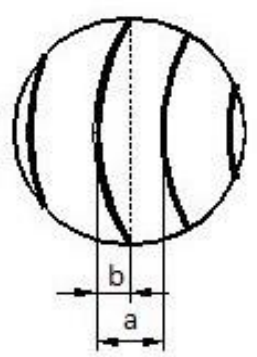

Figure 3 Fringe deviation and spacing width.

Before applying an edge detection to an image, it is necessary to get the right images first. There are some factors need to be adjusted in DSLR camera in order to get expected image as stated in the previous research (Amdani, Pratiwi, Rahman \& Purwowibowo, 2016). The three main camera settings are aperture, shutter time, and ISO. Aperture is opening of the lens where the light comes in. The wider its opening, the smaller its sequence number (e.g. form wide to small open $f / 1, f / 2, f / 4$, etc.). Shutter time is duration of the camera sensor to absorb the light. It varies from $1 / 4000$ s to 30 s. ISO is proportion of sensor sensitivity to the light. Smaller number means less sensitive. The term ISO stands for "International Organisation for Standardisation". However, camera ISO does not directly refer to the organisation that creates various technology and product standards. Two film standards called ASA and DIN were referred to as one word "ISO" from that point on.

One of an easiest way to automatically segment an image by computer is thresholding. By selecting certain intensity value as threshold, images can be segmented. The intensity which is above threshold is categorized as white pixel and the other is black pixel (Carabia \& Martín, 2012). Segmentation in the Otsu method is based on the intensity value of the image pixels that is plotted into histogram (Vala \& Baxi, 2013). The optimum intensity value in the histogram is the threshold value. The sequence formula to calculate the threshold is presented in formula (2) to (6) based on (Sezgin, 2014)

$P_{i}=\frac{n_{i}}{N}$

Cummulatives sum

$P_{1}(k) \sum_{i}^{k} P_{i}$

Cummulatives mean

$m(k) \sum_{i=0}^{k} i P_{i}$

Global intensity mean

$m_{G}=\sum_{i=0}^{L-1} i P_{i}$

Between-class variance

$\sigma_{B}^{2}=\frac{\left[m_{G} P_{1}(k)-m(k)\right]^{2}}{P_{1}(k)\left[1-P_{1}(k)\right]}$

When $\sigma_{B}^{2}$ is maximum, then the value of $\mathrm{k}$ is determined as the threshold

Where :

$P_{i} \quad$ : $\quad$ Probability each pixel in grey

$n_{i} \quad: \quad$ Pixel sum in each intensity

$N \quad$ : $\quad$ Total pixel from $n_{L}$ to $n_{L-1}$

$K$ : Threshold value in a grey level image which has range value from 1 to $L$ ( $L$ is the maximum luminance value in the image, the value for 8-bit quantization is typically 255 )

$P_{1}(k)$ : $\quad$ Sum of $P i$ from grey level $i$ to threshold $\mathrm{k}$

$\sigma_{B}^{2} \quad$ : Variance difference between foreground (object) and background 
$m(k), m_{G} \quad$ : Sum of foreground and background mean as function of the thresholding value $k$, foreground and background refer to the degree of which the gray level i belong to object and background respectively

Validation of the measurement results is analyzed through degree equivalence equation (7) which is described by (Filipe, 2010). In order to have calculation of the degree equivalence, the uncertainty budget of the measurement is required (Wimmer \& Witkovský, 2013).

$E_{n}=\frac{x_{1}-x_{2}}{2 \sqrt{u^{2}\left(x_{1}\right)+u^{2}\left(x_{2}\right)}}$

\section{Where :}

$\mathrm{X}_{1} \quad$ : value of reference

$\mathrm{X}_{2} \quad$ : value of test

$\mathrm{C}_{1} \quad$ : uncertainty of reference value

$\square_{2} \quad$ : uncertainty of test value

\section{METHODS}

Optical samples were measured using manual technique and image processing technique. Both techniques were carry out by comparison with an optical flat standard and illuminated using green monochromatic lamp. The optical flat samples are made from fused silica which have diameter $25 \mathrm{~mm}, 45 \mathrm{~mm}$, and $75 \mathrm{~mm}$. The samples are selected according to the requirement of the customer which mostly on those sizes. The thickness of the optical flat depend on the diameter and it has been standardised. So, for the same diameter would have the same thickness despite the manufacturer. Mainly the material of the commercial optical flat are fused silica, then varying the refractive index due to different material of the optical flat are not necessary. he light source is green monochromatic lamp. The fringe is seen through $3 \mathrm{~mm}$ window glass screen. It is measured at room temperature $(20 \pm 1)^{\circ} \mathrm{C}$ and under $65 \% \mathrm{RH}$. The measurement was performed by 3 people to know the reproducibility of the measurement.

In the existing manual system, the measurement is performed using ruler with resolution $0.5 \mathrm{~mm}$. Illustration of the system is described in Figure 4 (Amdani, Rahman, Pratiwi \& Purwowibowo, 2017). When the fringe pattern is formed in the Figure 4, the fringe deviation width (b) and the fringe spacing width (a) is observed by naked eyes and measured manually with $0.5 \mathrm{~mm}$ ruler. The measurements are repeated 10 times. Finally, the flatness value is calculated based on equation (1).

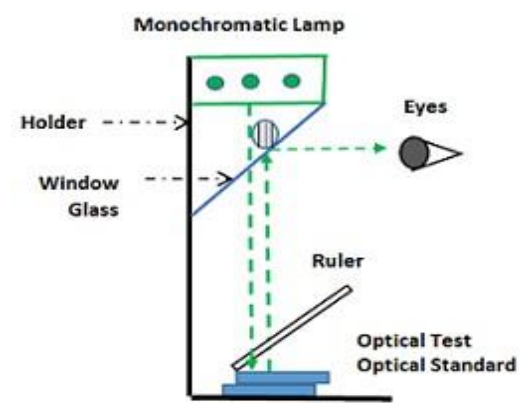

Figure 4 The existing manual system.

In the image processing technique, the camera type to capture fringe image is Nikon D3200. Interpretation of the system is shown in Figure 5.

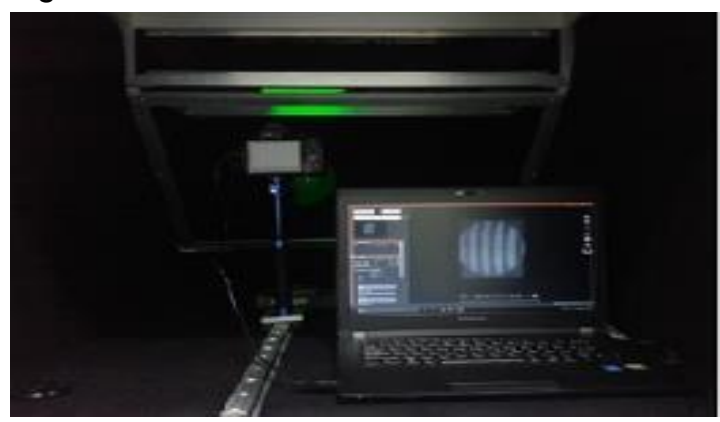

Figure 5. Image processing technique measurement

The figure shows after the fringe pattern is formed, then the fringe is captured with digital camera which has camera setting on focal length 35, ISO 200, aperture f/10, and shutter time 1s. The camera is controlled with DIGICAM free software to capture the images automatically through computer The result is examined with program developed in MATLAB. The written program is described below: I = imread('filename');

$12=\operatorname{imcrop}\left(I,\left[\begin{array}{llll}x_{1} & x_{2} & x_{3} & x_{4}\end{array}\right.\right.$

]); level = graythresh(I2)

I3=im2bw(I2,level);

I4=edge(I3,'Canny');

Imtool (14) =im2bw(I2,level);

I4=edge(I3,'Canny');

Imtool (14) 

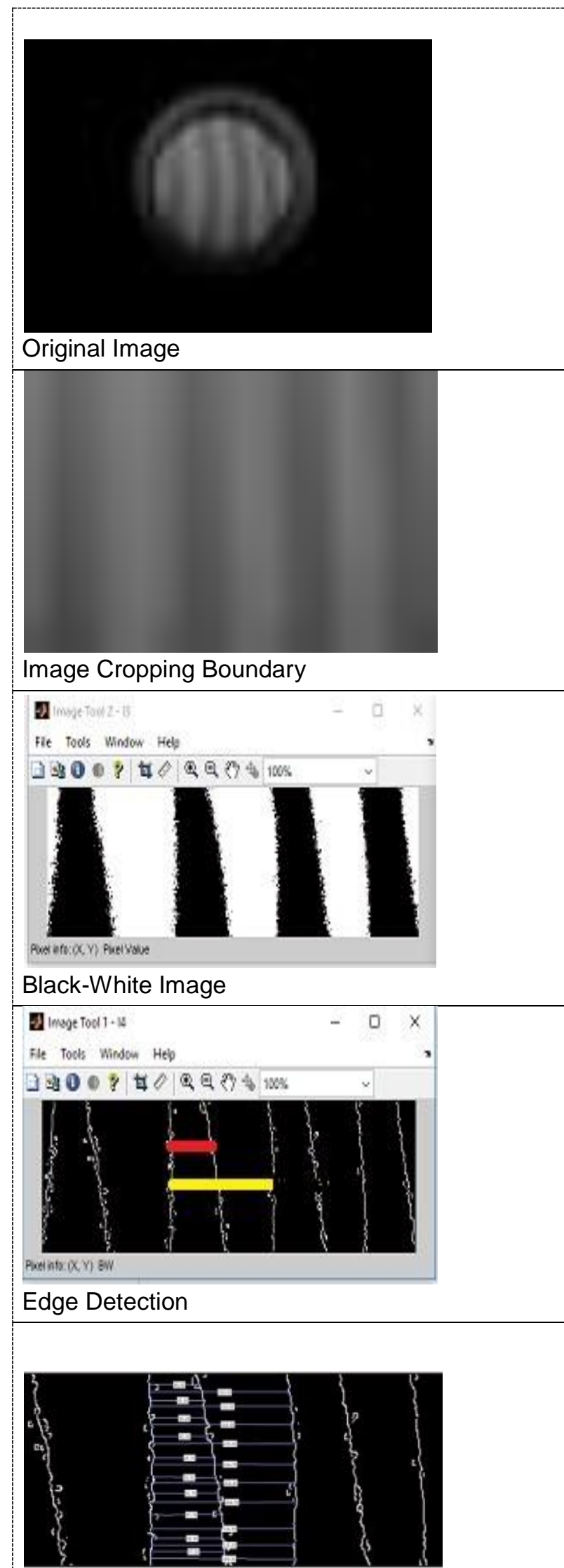

10 points measurement (manually selected)

Figure 6 Illustration of the image execution.
The execution is started by reading the image to be analysed. Fringe image area is still manually determined by entering pixel coordinate of $x_{1}, x_{2}, x_{3}$, $x_{4}$. Before turning the images to be black and white, a global computation based on Otsu method is used to determine the images threshold. This method allows to get automatic threshold value without manually input from the user. The threshold is computed using sequences of formula (2) to (6). However, it simply can be performed by command prompt

"graythresh" from MATLAB in the Image Processing Toolbox which is implemented with this Otsu method. This threshold then creates binary images by turning all pixels below the threshold value to zero and all pixels about that threshold to one. Zero refers to black, whilst one is on the contrary, it refers to white. The program then can be able to perform edge detection by Canny method.

The desired fringe is also still manually selected. After the determined fringe has been successfully detected by Canny method, the fringe deviation width and fringe spacing width is calculated using computer. The flatness calculation program is also based equation (1). The measurements are also still manually determined in 10 point of the selected fringe. Illustration of the program execution steps to process the images are presented in Figure 6.After the measurements are performed with both techniques, measurement results of the image processing technique and the manual technique are compared through degree equivalence evaluation of equation (7). The degree equivalence value is analysed whether the image processing technique measurement results have the measuring value agreement with the manual technique measurement results.

\section{RESULT AND DISCUSSION}

Flatness measurement results of each observer in each sample diameter are presented in the Table 1. Initial letters of the observers are given by $\mathrm{R}, \mathrm{T}$, and $\mathrm{N}$. The manual and image processing measurements are given by initial letter $\mathrm{M}$ and I. From the manufacture specification, it is only known that the sample has 0,1 flatness and the grade category is not stated. The table result shows that the flatness value of both manual and images technique are still in 0.1 range. Generally, it means that the result has no big difference compared to its specification. As mentioned in the JIS B74307431: 1977, the permissible value of flatness for grade 2 and 3 are 0.1 $\mu \mathrm{m}$ and $0.2 \mu \mathrm{m}$ respectively. From the measurement result, it is possible to have some value that out of the requirement if it is categorised in grade 2. By this comparison, it means that the result still needs an 
improvement for both manual and images technique to fill the requirement. However, the result is not in step to be validated yet with the interferometry measurement result to get the exact value should be. This research is still focused on the comparison of the manual and images technique result to know whether the performance of image processing technique is well enough to replace the manual technique for future improvement.

Table 1 Measurement result of different observer.

\begin{tabular}{|c|c|c|c|c|c|c|}
\hline \multirow{3}{*}{$\begin{array}{l}\text { Diameter } \\
\text { Mode } \\
\text { Unit }\end{array}$} & \multicolumn{2}{|c|}{$25 \mathrm{~mm}$} & \multicolumn{2}{|c|}{$45 \mathrm{~mm}$} & \multicolumn{2}{|c|}{$75 \mathrm{~mm}$} \\
\hline & M & I & $\mathbf{M}$ & I & M & I \\
\hline & $\mu \mathrm{m}$ & & $\mu \mathrm{m}$ & & $\mu \mathrm{m}$ & \\
\hline Observer 1 & $0 . \overline{11}$ & 0.12 & 0.10 & 0.12 & 0.10 & 0.13 \\
\hline Stdev & 0.007 & 0.012 & 0.005 & 0.013 & 0.002 & 0.006 \\
\hline Observer 2 & 0.12 & 0.12 & 0.09 & 0.12 & 0.10 & 0.13 \\
\hline Stdev & 0.005 & 0.012 & 0.003 & 0.016 & 0.001 & 0.004 \\
\hline Observer 3 & 0.11 & 0.12 & 0.09 & 0.12 & 0.09 & 0.13 \\
\hline Stdev & 0.010 & 0.012 & 0.002 & 0.014 & 0.002 & 0.005 \\
\hline
\end{tabular}

$\mathrm{M}$ : Manual technique

I : Image Processing Technique

The given table 1 shows that the standard deviation of image processing technique is obtained from single image and taken from 10 points measurement of the selected fringe. Compared to the manual result, the image processing technique has bigger standard deviation. It has varying value along the 10 points measurement on the selected fringe. It is caused by the simple written program that could not segment the images well. The points measurement is also still manually selected. The segmentation will affect the edge detection of the images which has to represent the original images as well. If it is not get well detection, then it can form imperfect fringe curve that cause varying value obtained along the fringe. However, the final result of all observers give the same value for each diameter samples. The summary of all observer measurement result and validation are presented in the table 2

Table 2 Summary result and validation.

\begin{tabular}{cccccccc}
\hline Diameter & \multicolumn{2}{c}{$25 \mathrm{~mm}$} & \multicolumn{2}{c}{$45 \mathrm{~mm}$} & \multicolumn{2}{c}{$75 \mathrm{~mm}$} \\
Mode & $\mathbf{M}$ & $\mathbf{I}$ & $\mathbf{M}$ & $\mathbf{I}$ & $\mathbf{M}$ & $\mathbf{I}$ \\
Unit & \multicolumn{2}{c}{$\boldsymbol{\mu m}$} & \multicolumn{2}{c}{$\boldsymbol{\mu m}$} & \multicolumn{2}{c}{$\boldsymbol{\mu m}$} \\
\hline Average & 0.11 & 0.12 & 0.09 & 0,12 & 0,10 & 0,13 \\
\hline Stdev & 0.006 & 0.004 & 0.006 & 0,004 & 0,006 & 0,003 \\
\hline En & \multicolumn{2}{c}{0.02} & \multicolumn{2}{c}{0.09} & \multicolumn{2}{c}{0.11} \\
\hline
\end{tabular}


The expanded uncertainty for both manual and image processing technique with coverage factor $\mathrm{k}=2$ are given $0.11 \mu \mathrm{m}$ and $0.10 \mu \mathrm{m} .$. It is detailed further in table 3 and 4.

Table 3 Uncertainty budget for manual technique

\begin{tabular}{|c|c|c|c|c|}
\hline Uncert source & Unit & Symbol & $\begin{array}{l}\text { Sens. } \\
\text { Coeff/ } \\
\text { ci }\end{array}$ & $\begin{array}{l}\text { Std. } \\
\text { Uncert/ } \\
\text { ui }\end{array}$ \\
\hline $\begin{array}{l}\text { Optical flat } \\
\text { certificate }\end{array}$ & $\mu \mathrm{m}$ & $\mathrm{u}(\mathrm{FB})$ & 1.00 & 0.0500 \\
\hline $\begin{array}{l}\text { Monochromatic } \\
\text { lamp certificate }\end{array}$ & $\mu \mathrm{m}$ & $\mathrm{u}(\lambda 1)$ & 0.50 & 0.0001 \\
\hline $\begin{array}{l}\text { Scale } \\
\text { measurement }\end{array}$ & $\mu \mathrm{m}$ & $u(\lambda 2)$ & 0.50 & 0.0133 \\
\hline Repeatability & $\mu \mathrm{m}$ & $u(\lambda 3)$ & 0.50 & 0.0032 \\
\hline Targeting Error & $\mu \mathrm{m}$ & $u(\lambda 4)$ & 0.50 & 0.0346 \\
\hline \multicolumn{3}{|c|}{ Combined uncertainty } & Uc & 0.0534 \\
\hline \multicolumn{3}{|c|}{ Expanded Uncertainty at $\mathrm{k}=2$} & $U(k=2)$ & 0.11 \\
\hline
\end{tabular}

The consistency of image processing technique is shown by the standard deviation from all observer final result. It is known to be smaller than the manual technique. It means that the image processing technique result has consistency whoever its observer. Validation is presented by degree equivalence (En) of the average measurement result from all observer. The En number for each diameter samples are below 1. It means that the measurement result of image processing technique has value agreement with the manual technique measurement.

Table 4 Uncertainty budget for image processing technique.

\begin{tabular}{lllll} 
Uncert source & Unit & Symbol & $\begin{array}{l}\text { Sens. } \\
\text { Coeff/ } \\
\text { ci }\end{array}$ & $\begin{array}{l}\text { Std. } \\
\text { Uncert/ } \\
\text { ui }\end{array}$ \\
\hline $\begin{array}{l}\text { Optical flat } \\
\text { certificate }\end{array}$ & $\mu \mathrm{m}$ & $\mathrm{u}(\mathrm{FB})$ & 1.00 & 0.0500 \\
\hline $\begin{array}{l}\text { Monochromati } \\
\text { c lamp } \\
\text { certificate }\end{array}$ & $\mu \mathrm{m}$ & $\mathrm{u}(\lambda 1)$ & 0.50 & 0.0001 \\
\hline $\begin{array}{l}\text { Scale } \\
\text { measurement }\end{array}$ & $\mu \mathrm{m}$ & $\mathrm{u}(\lambda 2)$ & 0.50 & 0.0133 \\
\hline Repeatability & $\mu \mathrm{m}$ & $\mathrm{u}(\lambda 3)$ & 0.50 & 0.0051 \\
\hline
\end{tabular}

\begin{tabular}{llll}
\hline Targeting Error $\mu \mathrm{m}$ & $\mathrm{u}(\lambda 4)$ & 0.50 & 0.0173 \\
\hline Combined uncertainty & $\mathrm{Uc}$ & 0.0512 \\
\hline Expanded Uncertainty at $\mathrm{k}=2$ & $\mathrm{U}(\mathrm{k}=2)$ & 0.10 \\
\hline
\end{tabular}

\section{CONCLUSION}

Based on the degree equivalence evaluation, it can be concluded that the measurement results of image processing technique have been verified to the manual technique through degree equivalence evaluation. The image processing technique has good performance and can be implemented to the flatness measurement. However, it needs to develop the analysed program to remove the manually determined selection that can cause varying value measurement for future improvement.

\section{ACKNOWLEDGEMENT}

The authors thanks to all of member length laboratory and Indonesian Institute of Sciences agency for financial support to this research and providing facilities that make this work possible at those time.

\section{DAFTAR PUSTAKA}

Air Wedge Interference Picture [Image] (n.d.). Retrieved from https://images.slideplayer.com/13/3866 240/slide s/slide_41.jpg

Interference Pattern Formation Picture [Image] (n.d.). Retrieved from

https://www.telescopeoptics.net/testing_optica I_quality.htm

Amdani, R. Z, Pratiwi, E, Rahman, R, \& Purwowibowo. (2016). Studi awal pengaturan kamera untuk deteksi tepi pada citra frinji. PPI KIM 42, ISSN 0852$002 \mathrm{X}$.

Abo-Zahhad, M., Gharieb, R. R., Ahmed, S. M., \& Donkol, A. A. E. B. (2014). Edge detection with a preprocessing approach. Journal of Signal and Information Processing, 5(04), 123-134

Amdani, R. Z., Rahman, A., \& Pratiwi, E. (2017). A study of comparison between window glass and mirror on flatness measurement in RCM LIPI. Procedia Engineering, 170, 352-356 
Carabia \& Martín, D. (2012). Image thresholding methods for their application to augmented reality environments. Unpublished Master Thesis. Universidad Complutense De Madrid.

De Groot, P., Biegen, J., Clark, J., de Lega, X. C., \& Grigg, D. (2002). Optical interferometry for measurement of the geometric dimensions of industrial parts. Applied Optics, 41(19), 3853-3860.

Firmansyah, I., Priyatikanto, R., \& Aria, U. J. (2015). Fotometri pleiades menggunakan kamera DSLR. Spektra: Jurnal Fisika dan Aplikasinya, 16(3), 15.

Filipe, E. (2010). Validation of measurement capabilities. Measurement, 43, 690-693

Gonzalez, R.C, Woods, R. E, \& Eddins, S.L. (2009). Digital image processing using matlab. USA : Gatesmark Publishing

Wimmer, G \& Witkovský, V. (2013). New procedure for calculating the uncertainty of one output quantity in calibration certificates. Measurement SPIE, 7018 701817-1

JIS B 7430-7431. (1977). Optical flat-optical parallel.

Rashmi, Kumar, M., \& Saxena, R. (2013). Algorithm and technique on various edge detection: A survey. Signal \& Image Processing, 4(3), 65.

Sezgin, M., \& Sankur, B. (2004). Survey over image thresholding techniques and quantitative performance evaluation. Journal of Electronic imaging, 13(1), 146166.

Vala, H. J., \& Baxi, A. (2013). A review on Otsu image segmentation algorithm. International Journal of Advanced Research in Computer Engineering \& Technology (IJARCET), 2(2), 387-389.

Xu, C., Chen, L., \& Yin, J. (2009). Method for absolute flatness measurement of optical surfaces. Applied optics, 48(13), 2536-2541 